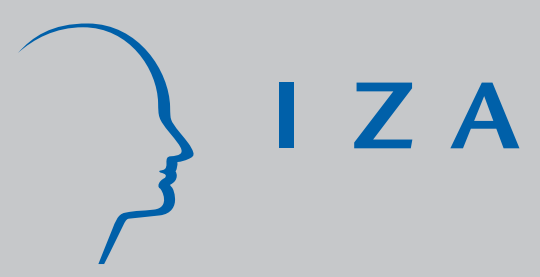

IZA DP No. 2453

Employment Effects of Privatisation and Foreign Acquisition of Chinese State-Owned Enterprises

Yundan Gong

Holger Görg

Sara Maioli

November 2006 


\title{
Employment Effects of Privatisation and Foreign Acquisition of Chinese State-Owned Enterprises
}

\author{
Yundan Gong \\ University of Nottingham \\ Holger Görg \\ GEP, University of Nottingham \\ and IZA Bonn \\ Sara Maioli \\ University of Newcastle

\section{Discussion Paper No. 2453 \\ November 2006} \\ IZA \\ P.O. Box 7240 \\ 53072 Bonn \\ Germany \\ Phone: +49-228-3894-0 \\ Fax: +49-228-3894-180 \\ E-mail: iza@iza.org
}

\begin{abstract}
Any opinions expressed here are those of the author(s) and not those of the institute. Research disseminated by IZA may include views on policy, but the institute itself takes no institutional policy positions.

The Institute for the Study of Labor (IZA) in Bonn is a local and virtual international research center and a place of communication between science, politics and business. IZA is an independent nonprofit company supported by Deutsche Post World Net. The center is associated with the University of Bonn and offers a stimulating research environment through its research networks, research support, and visitors and doctoral programs. IZA engages in (i) original and internationally competitive research in all fields of labor economics, (ii) development of policy concepts, and (iii) dissemination of research results and concepts to the interested public.
\end{abstract}

IZA Discussion Papers often represent preliminary work and are circulated to encourage discussion. Citation of such a paper should account for its provisional character. A revised version may be available directly from the author. 
IZA Discussion Paper No. 2453

November 2006

\section{ABSTRACT \\ Employment Effects of Privatisation and Foreign Acquisition of Chinese State-Owned Enterprises}

This paper investigates the effects of domestic privatisation or foreign acquisition of Chinese State Owned Enterprises (SOEs) on employment growth, using firm level data for China and a combination of propensity score matching and difference-in-differences in order to identify the causal effect. Our results suggest that, controlling for output growth there is some evidence that domestic privatisation leads to contemporaneous reductions in employment growth compared to firms that did not undergo an ownership change. By contrast, there is some evidence that foreign acquisitions show higher employment growth in the post acquisition period than non-acquired SOEs.

JEL Classification: P2, F2

Keywords: privatisation, foreign acquisition, employment growth, difference-in-differences

Corresponding author:

Holger Görg

School of Economics

University of Nottingham

University Park

Nottingham NG7 2RD

United Kingdom

E-mail: holger.gorg@nottingham.ac.uk

\footnotetext{
* The authors are grateful to Sourafel Girma for very useful discussions and suggestions, and an anonymous referee for helpful comments. Holger Görg gratefully acknowledges financial support from the Leverhulme Trust Programme Grant F114/BF.
} 


\section{Introduction}

China has undergone dramatic economic changes since it started its opening-up and liberalisation programs in 1978, moving from being a centrally planned economy to a middle income, emerging market economy at the turn of the millennium. Indeed, the country is now a rapidly growing manufacturing base, exporting nation, and recent member of the World Trade Organisation (WTO); issues that have stirred much recent debate in the popular press as well as among academics. Economic reforms have had particular implications for Chinese State-owned enterprises (SOEs), boosting enormously total factor productivity ( $\mathrm{Li}, 1997)$ largely by improving incentive for managers and workers (Groves et al., 1994, 1995) and decentralising economic decision-making (Cao et al. 1999, Lau et al. 2000).

From being by far the dominant form of enterprise in pre-reform China, their importance has declined rapidly over the last two decades, both because of the emergence of the private sector, and the massive privatisation program launched at the end of the 1990s which aimed at selling all but the largest 300 or so SOEs (Lin, 2000 and Megginson and Netter, 2001). Still, the welfare of tens of millions of urban workers, and the generation of adequate state revenues depend to a large extent on the success of SOEs. However, Lin et al. (1998), for example, argue that without state subsidies, protection and easy access to bank credits, the majority of SOEs would be on the verge of collapse. Hence, reforming SOEs in order to enable them to compete successfully on domestic and international markets is of utmost importance for sustained growth of the Chinese economy.

One possible route through which SOEs may become more efficient and competitive is through privatisation (Lin et al., 1998). This can be either a privatisation on the domestic market, i.e., the private owners being Chinese nationals, or through foreign 
direct investment, with the Chinese firm being acquired (partly or fully) by foreign multinationals. Both of these routes are considered in this paper. We are particularly concerned with investigating the effects of domestic privatisation and foreign acquisition on employment growth in the Chinese firm.

From a policy perspective this research question is motivated by two concerns. On the one hand, privatisation or indeed any change of ownership may have implications for "safeguarding jobs" as workers may be set off in a move to reduce the labour force in an attempt to streamline production. On the other hand, a possible reduction in the workforce may be necessary to improve efficiency and productivity in the SOEs. Our specific research in this paper focuses more on the latter aspect. We look at the efficiency effects of privatisation/acquisition by examining the effect on employment growth controlling for contemporaneous output growth. ${ }^{1}$

The identification of the causal effect of ownership change on employment is hampered by a possible selection bias. If SOEs that have certain characteristics which are correlated with employment growth (e.g., size or productivity) are more likely to be targets for domestic privatisation or foreign acquisition, then a comparison of post ownership change employment growth with that of a randomly selected control group is problematic and may lead to biased results. In this paper we address this issue through a combination of propensity score matching and difference-in-differences techniques. Firstly, we use propensity score matching (e.g., Rosenbaum and Rubin, 1983) to identify a control group of matched firms that are similar in characteristics to those firms that

\footnotetext{
${ }^{1}$ An empirical investigation of the privatisation effects on employment levels in China is also particularly interesting because of the role played by SOEs. As noted in Megginson and Netter (2001), Chinese SOEs, rather than the government itself, serve as the country's social safety net, thus in China SOEs are burdened with many social welfare responsibilities (Bai et al., 1997 and Lin et al., 1998). Since there were concerns, when the massive privatisation program was launched, that the government would not have granted privatised firms discretion over staffing levels or subjected them to truly enterprise-threatening competition (Megginson and Netter, 2001), it is interesting to investigate whether those concerns were ill founded a few years after the launch of the privatisation program.
} 
experienced an ownership change. We then run a difference-in-differences econometric model on the matched sample of firms in order to identify the causal effect of ownership change on employment growth, controlling for other characteristics that are presumed to affect labour demand.

The remainder of the paper is structured as follows. Section 2 discusses the related literature. The data and econometric approach are presented in Section 3 while Section 4 outlines the main empirical findings. A summary and conclusion can be found in Section 5.

\section{Literature Review}

Evaluating the effectiveness of privatisation programs in improving economic and financial performance of divested firms has received a great deal of attention in the literature. Theory is inconclusive about the merits of government vs. private ownership in promoting efficiency, as pointed out by Laffont and Tirole (1993). Basically, government intervention in the economy is required when there exists some form of market failure whereas privatisation is the response to state ownership failure. Welfare economics suggests that privatisation tends to reap the highest gains when SOEs operate in already competitive markets or markets that can readily become competitive, i.e. when the market failure problem is less severe. In contrast, the arguments for privatisation are weaker in markets for public goods and natural monopolies where competition is dwarfed. However even in the latter case, as discussed by Megginson and Netter (2001), private ownership is 
generally considered more appropriate than the public one because, among other things, it is easier to have a well-defined and stable corporate goal under private ownership. ${ }^{2}$

Considering property rights and agency costs problems, the superior performance of privately-owned firms compared to state-owned ones arises since the former possess a broader range of monitoring devices. Moreover, SOEs may be more inefficient if they receive government funding or are bailed out by the state in case of insolvency, leading to soft budget constraints. This is typical of firms under communist regimes, where hard budget constraints are generally ineffective even when formally imposed. ${ }^{3}$ Of course the theory about privatisation does not argue that state intervention is bad per se, but that it is more harmful if pursued with state ownership than with state regulation.

The empirical literature that has compared the performance of SOEs to privatised or private firms has principally investigated the effects of privatisation on measures of productive efficiency, productivity, profitability, cost reduction, factor intensity, corporate value, level of indebtness, investment and employment. All empirical work in this area faces the problems of selection bias, endogeneity, omitted variables, lack of data or inadequate data, to a different extent. ${ }^{4}$ It is therefore important to have access to adequate data and use econometric techniques that allow controlling for these problems. Despite these concerns, many studies - as surveyed in Megginson and Netter (2001) - have managed to compare SOEs and private firms’ performance using different methodologies

\footnotetext{
${ }^{2}$ For example, even if governments pursue a profit-maximising goal for the firm it is difficult to write complete contracts that tie managers' incentives to that goal because of diffuse ownership (e.g., Shleifer, 1998).

${ }^{3}$ See, for example, Kornai $(1988,1993)$ and Frydman et al. (2000).

${ }^{4}$ Selection bias is due to the possibility that best performing firms are selected for privatization. Endogeneity, as explained in Megginson and Netter (2001, p. 332) has to do with the "fundamental reasons why certain firms are government owned and others are privately owned, including the degree of perceived market failure within the particular industry. The factors [...] also have significant effects on performance. Thus, it is difficult to evaluate the effects of government ownership where the ownership structure is itself endogenous to the system that includes both political and performance goals”. Arguably, in a centrally planned or transition economy this type of endogeneity is less of an issue as all industries were formerly state owned.
} 
but reaching in the majority of cases similar results across countries, industries and periods of time.

The most consistent result found is that performance differs between SOEs and privately held firms, with the latter showing significant higher productivity or efficiency and profitability, even after controlling for size, market share, technical changes and other market conditions. ${ }^{5}$ And this seems important when analysing non developed or developing countries.

A word of caution must be said when examining the effects of privatisation carried out in any transition country: the difficulty in disentangling the effects of privatisation alone from the effects due to the contemporaneous deregulation and market liberalisation usually taking place at the same time as privatisation. Some argue that competition and regulation are more important than privatisation or governance changes in improving the performance of firms, ${ }^{6}$ while others are convinced that privatisation is necessary for significant performance improvements. ${ }^{7}$ For China, Groves et al (1994) and Li (1997) provide some evidence that enterprise restructuring through an improvement in the allocation of property rights and incentives can yield large benefits even without privatisation. However, Shirley and Xu (1998) reach the opposite conclusion. ${ }^{8}$

\footnotetext{
${ }^{5}$ For example see Vining and Boardman (1992) and Ehrlich et al. (1994).

${ }^{6}$ See for example Bishop and Kay (1989), Vickers and Yarrow (1991) and Allen and Gale (1999).

${ }^{7}$ Among others, Boycko, Shleifer and Vishny (1994), Nellis (1994), Brada (1996) and Shleifer (1998).

${ }^{8}$ Unfortunately, as Megginson and Netter (2001) note, it is very difficult to obtain evidence on whether economic reform coupled with privatisation could lead to even bigger performance improvements. A study that considers both the effects of competition and privatisation is Ros (1999) for main telecoms in 110 countries and finds that both reforms increase efficiency but only privatisation increases network expansion. Boyland and Nicoletti (2000) also investigate the contemporaneous effects of privatisation and liberalisation on cellular telephone services in 23 OECD countries and find that whilst competition does increase productivity and lowers prices, privatisation has no clear effects. Wallsten (2001) explores the effects of privatisation, competition and regulation on telecommunication performance in 30 African and Latin American countries and concludes that increasing competition is the single best reform; competition in combination with privatisation is the best, while privatising a monopoly without regulatory reforms is to be avoided. Notice that all these three studies are about telecommunication industries, no evidence is available which is broader in scope.
} 
Concerning in particular the empirical literature on the employment effects of privatisation, the results are less unanimous than for productivity or profitability. Studies that document decreases, sometimes quite substantial, in employment levels following privatisation are, for example, Ramamurti (1997) using data for the national Argentinean railroad Ferrocarilla Argentinos; La Porta and López-de-Silanes (1999) for 218 Mexican SOEs; D’Souza and Megginson (1999) for 78 firms from both developed and developing countries; Boardman, Laurin and Vining (2002) for 9 Canadian firms; and Harper (2002) for 174 Czech firms in a first wave, and 380 in a second wave of privatisations. By contrast, studies that found no significant change in employment after privatisation include Macqueira and Zurita (1996) for 22 Chilean firms; D’Souza and Megginson (2000) for 17 national telecom companies. Furthermore, three studies document an increase in employment: Galal et al. (1994); Megginson, Nash and van Randenborgh (1994) for 61 firms from 18 countries; Boubakri and Cosset (1998) for 79 firms from 21 developing countries. As pointed out in Megginson and Netter (2001), these conflicting results could be partly explained by different methodologies, sample size or omitted factors. But they could also reflect genuine differences between countries and industries analysed, meaning that no standard outcome is expected in terms of employment changes in privatised firms.

However, one issue that has not received much investigation in the literature is whether the sale of divested firms to domestic vs. foreign buyers can have different effects on the subsequent performance of such privatised firms. Among the few studies that analyse the impact of domestic vs. foreign ownership on performance are Smith, Cin and Vodopivec (1997), Dyck (1997), Djankov (1999) and Frydman et al. (1999) and they 
document that foreign ownership is associated with greater post-privatisation performance improvement than is purely domestic ownership. ${ }^{9}$

To the best of our knowledge, however, only Frydman et al. (1999) analyse whether the foreign ownership of newly privatised firms in Poland, Hungary and Czech Republic may have a different impact on employment levels than domestic ownership. They find that foreign-owned privatised firms are 'softer' on employment reductions than domestic ones (controlling for revenue and productivity growth). Possible interpretations of this result suggested by the authors are that foreign owners can afford a longer-term perspective, that they are reluctant to lay off workers to avoid mistrust, or simply that they are prevented from doing it by explicit or implicit agreements in the purchase contracts. Given the interest for China in evaluating the employment evolutions in recent years for privatised SOEs we consider this a motivation for our study for distinguishing between domestic and foreign-led (through cross-border acquisition) privatisations.

Moreover, in our study we pay particular attention to the selection problem. Only a few studies have attempted to control for selection, using different approaches. Some studies compare post-privatisation performance changes with either a comparison group of randomly selected SOEs or with a counterfactual expectation of what would have occurred if the privatised firms had remained state-owned. ${ }^{10}$ One illustration is the study by Frydman et al. (1999) who use survey data for Czech Republic, Hungary and Poland in 1994. They use a fixed effects model to control for selection bias caused by unobserved firm characteristics correlated with performance outcomes that are fixed over time. Then they compare the performance of firms privatised in one period with those privatised in

\footnotetext{
${ }^{9}$ Not all countries have favoured a privatisation process through FDI. In the case of Eastern and Central Europe for example Hungary was in this sense an exception, and it is exactly for this reason Mihályi (2000) argues that its transition towards a market economy has been more successful than most of other CEECs countries, since the divested firms can enter swiftly in the global trading system.

${ }^{10}$ See Galal et al. (1994), Newberry and Pollitt (1997), La Porta and López-de-Silanes (1999)
} 
another for two time periods, in order to contrast the privatised firms with how they would have performed without privatisation. As a further control for selection bias, they compare the pre-privatisation performance of managerially-controlled firms with those of firms controlled by other owners.

Rather than relying on such methods to deal with selection we use instead a combination of propensity score matching and difference-in-differences techniques, which to the best of our knowledge has never been used in studies on privatisations. ${ }^{11} \mathrm{We}$ describe the details of this estimation approach in the following section.

\section{Data and methodology}

For our empirical analysis we draw on the Annual Report of Industrial Enterprise Statistics compiled by the State Statistical Bureau of China, covering all firms with annual turnover of over five million Renminbi (roughly $\$ 0.6$ million). The data set includes variables such as firm ownership structure, industry affiliation, establishment year, employment, gross output, value added, exports, fixed assets, and bank credit. ${ }^{12}$ The data available to us and used in this study cover the period 1999 to 2003.

Broadly speaking Chinese firms are classified under four ownership categories: (i) state-owned (ii) privately-owned (iii) foreign-owned, and (iv) collectively-owned. Since the focus of this paper is on isolating the employment effect of domestic privatisation and foreign acquisition of state-owned owned enterprises, collectively-owned firms and firms that remained in private or foreign hands during the entire sample period are dropped from our analysis. Also firms with less than 3 observations are omitted given the need to have

\footnotetext{
${ }^{11}$ The method has been employed by Girma (2005) in the context of identifying the employment effects of foreign acquisitions in the UK and we largely follow his approach in this paper.

${ }_{12}$ Nominal values are deflated using industry-specific ex-factory price indices obtained from China Statistical Yearbook 2004.
} 
data during the pre and post ownership change period. Thus our working sample consists of all firms with at least three time series observations and that have either remained in state ownership between 1999 and 2003 (the control group) or had started as state-owned enterprises and ended up in either domestic or foreign investors hands (the treatment group).

As discussed above, the major problem in evaluating the effect of privatisation / acquisition is that the treatment is most likely not random. Rather, certain types of firms may be selected as targets based on their pre-treatment characteristics. There are, in general, a number of ways of dealing with this selectivity problem, using, e.g., instrumental variables regressions, difference-in-differences (DID) analysis, or propensity score matching. All of these approaches rest on specific assumptions for the technique to be valid. As argued by Blundell and Costa Dias (2000) a combination of matching and difference-in-differences analysis arguably improves the accuracy of an evaluation study and we follow this approach here. Hence, instead of using a straightforward propensity score matching estimator we employ the more general difference-in-differences estimator on the sample of matched firms to isolate the effects of the treatment on employment growth of erstwhile state owned enterprises. The specifics of the methodology within our context are outlined below.

We employ the method of propensity score matching due to Rosenbaum and Rubin (1983) to construct a sample of treated and control group firms. The idea behind the propensity score matching method is to use of the probability of receiving treatment (foreign acquisition or domestic privatisation in the present context) as the basis for matching a treated firm to a control firm. Accordingly, for each year, we first identify the probability of receiving treatment (or 'propensity score') via the following probit model

$$
P\left(\operatorname{TREAT}_{i t}=1\right)=F\left(X_{i t-1}, D_{i t}\right)
$$


where $\mathrm{D}$ is the full set of industry and regional dummies, and the vector $\mathrm{X}$ consists of debts, intangible assets, labour productivity, level and growth of employment in the pretreatment period. These variables, thus, control of aspects of firm performance preprivatisation that are likely to make them attractive targets for privatisation - e.g., foreign investors may "cherry pick” plants with high productivity, high growth, low debts and high intensity of intangible assets prior to privatisation.

For each firm $i$ that has undergone ownership change, a state-owned firm $\mathrm{j}$, which is 'closest' to it in terms of its propensity score is selected as a match using the 'caliper' matching method. ${ }^{13}$ The caliper method employs the nearest control firm whose propensity score falls within a pre-specified radius (which is set at 0.01 in our analysis) as a match for a treatment firm. Furthermore we impose the so-called common support condition in the matching algorithm. This involves dropping treatment firm observations whose propensity score is higher than the maximum or less than the minimum propensity score of the control group of firms. ${ }^{14}$ We refer to the resulting sub-sample of matched firms as the matched sample. Table 1 gives the frequency distribution of firms by year and treatment status for both the matched and unmatched sample.

\section{[Table 1 here]}

In order to estimate the impact of ownership change on employment growth in treated firms we adopt a differences-in-differences methodology on the matched sample. ${ }^{15}$ The first step proceeds by comparing the average employment growth $\dot{E}$ before treatment with its post-treatment counterpart. However, the resulting quantity, say, $\Delta^{a} \dot{E}$, is a biased

\footnotetext{
${ }^{13}$ The matching is performed in State Version 9 using the PSMATCH2 software provided by Leuven and Sianesi (2003). Note that since lagged employment growth is included in the matching probit, matching was done for 2001, 2002 and 2003.

${ }^{14}$ We were also careful to check that the specification of the propensity score model 'balances' the pretreatment variables between the treatment and control groups conditional on the propensity score (e.g. Dehejia and Wahba, 2002). Reassuringly we find from standard tests that the required balancing conditions are satisfied by the data. The test results are reported in the appendix.

${ }^{15}$ See Meyer (1995) for an excellent exposition of this methodology.
} 
estimator of the impact of the ownership change on employment growth since it is likely to be affected by other factors which are contemporaneous with the acquisition. Now consider the changes in employment growth of the control plants corresponding to the pre and post acquisitions periods, say, $\Delta^{C} \dot{E}$. If exogenous shocks which are contemporaneous with the acquisitions affect the acquired and control firms in more or less similar fashions (arguably a reasonable assumption for the matched sample), the differences-in-differences estimator which is defined as $\delta=\Delta^{a} \dot{E}-\Delta^{c} \dot{E}$ would purge the effects of common shocks and provide an unbiased estimator of the impact of ownership change.

To implement the above methodology within a regression framework, one can estimate the following equation, using the matched sample

$$
\dot{E}_{i t}=\alpha+\delta A_{i}+\varepsilon_{i t}
$$

Here $i$ and $t$ index plants and time periods respectively and $A$ is a vector of posttreatment dummies. In equation (2) the estimator for $\delta$ yields the average percentage point change in the growth rate of employment that can be attributed to privatisation or foreign acquisition. To allow for differential acquisition effects across the years, we construct two separate dummies, namely, a contemporaneous dummy and a second one for the period starting from one year after ownership change.

In our empirical implementation, we extend the basic regression framework and embed it into an empirical labour demand model, following Girma (2005) and Girma and Görg (2004). Hence, we control for wage growth and output growth as the main determinants of changes in labour demand in all regressions. ${ }^{16}$ Furthermore, a number of other plant characteristics are included to control for observable changes that are

\footnotetext{
${ }^{16}$ Note that when controlling for output growth, the post-treatment dummies simply reflect the change in employment growth induced by changes in efficiency, i.e., the increase in the use of labour for a given level of output growth.
} 
correlated with employment changes, namely age and the debt-to-asset (bank credit/total assets) ratio. Numerous studies of firm dynamics (e.g. Geroski, 1995) have shown that younger firms tend to grow faster than older ones. It is also well-documented that inefficient and near-bankrupt Chinese SOEs maintained their existence due to politicallymotivated easy access to bank credits and have been operating under soft budget constraints (e.g. Lin et al. 1998). Finally, we include a full set of time, sectoral and regional dummies to capture aggregate shocks and permanent differences in the trend of employment growth across sectors and regions, respectively.

We allow for different effects of the treatment on employment growth at different quantiles of the growth distribution. This allows us to take better account of possible heterogeneity in employment growth and in the treatment effect across establishments. While standard least squares technique (OLS) estimates the mean of the dependent variable conditional on the covariates we use the quantile regression estimator to estimate the effect of the covariates on different quantiles of the employment growth distribution.

The quantile regression technique was introduced by Koenker and Bassett (1978). ${ }^{17}$ Denoting the vector of regressors in the expanded version of equation (2) by $Z$, the quantile regression model can be written as

$$
\dot{E}_{i t}=Z_{i t}^{\prime} \beta_{\theta}+\varepsilon_{\theta i t}, \text { Quant }_{\theta}\left(\dot{E}_{i t} \mid Z_{i t}\right)=Z_{i t}^{\prime} \beta_{\theta}
$$

where Quant $_{\theta}\left(\dot{E}_{i t} \mid Z_{i t}\right)$ denotes the conditional quantile of $\dot{E}_{i t}$. The distribution of the error term $\varepsilon_{\theta}$ is left unspecified, so the estimation method is essentially semiparametric, and the $\theta^{\text {th }}$ quantile regression, $0<\theta<1$, solves

$$
\min _{\beta} \frac{1}{n}\left\{\sum_{i, t: \dot{E} \geq z^{\prime} \beta} \theta\left|\dot{E}_{i t}-Z_{i t}^{\prime} \beta\right|+\sum_{i, t: \dot{E}<z^{\prime} \beta}(1-\theta)\left|\dot{E}_{i t}-Z_{i t}^{\prime} \beta\right|\right\}
$$

\footnotetext{
${ }^{17}$ See Buchinsky (1998) for an excellent overview of quantile models.
} 
Thus by increasing $\theta$ from 0 to 1 , one can trace the entire distribution of SOEs employment growth, conditional on the set of regressors. In this study we consider regression estimates at five different quantiles, namely, the $10^{\text {th }}, 25^{\text {th }}, 50^{\text {th }}$ (median), $75^{\text {th }}$ and $90^{\text {th }}$ percentiles of the employment growth distribution.

\section{Empirical results}

By way of preliminary statistics, Table 2 presents average yearly growth rates of employment for the matched control group of purely state owned enterprises, SOEs that underwent a domestic privatisation and those that were acquired by foreign owners over the sample period. For the latter two groups, we distinguish average growth pre and post the "treatment". We report the mean growth rate as well as five quantiles of the growth distribution. Note, firstly, that the growth rate for pure SOEs is always lower than that for the treated firms pre-treatment, perhaps indicating that there is selection of privatisation and acquisition targets. The mean employment growth declines after treatment for SOEs undergoing a domestic privatisation or a foreign acquisition. This, however, is only true for firms undergoing a domestic privatisation when considering the lower quantiles of the growth distribution. Examination of the $75^{\text {th }}$ and $90^{\text {th }}$ quantile shows that employment growth is higher after than before the privatisation. Table 3 provides some further summary statistics on the variables included in the regression model for the full (unmatched) and matched (treated and untreated) sample. ${ }^{18}$

[Tables 2 and 3 here]

\footnotetext{
${ }^{18}$ Note that the matching and the appropriate balancing tests have been done on a year by year basis, while the summary statistics are calculated for the pooled sample. Hence, we would not necessarily expect to see evidence for "balancing" in these pooled summary statistics between the matched treated and untreated firms.
} 
The growth rates reported in Table 2 are, of course, only averages over fairly heterogeneous firms and, thus, hide the influence of other confounding effects. In order to be able to determine the causal effect of ownership change on employment growth we, therefore, turn to the econometric analysis as described in Section 3. In the first instance, we estimate a standard difference-in-differences approach (as in the "augmented” equation 2) on the full sample of firms, i.e., including all SOEs that remained in state ownership over the period, as well as those SOEs that changed ownership (i.e., received treatment). Table 4 reports these econometric estimates based on the full sample.

Reassuringly, wages and output growth, as well as age, have the expected signs across all quantiles and in the OLS (conditional mean) estimation. We also find evidence that a higher debt-to-asset ratio has adverse effects on firms' employment growth. These effects appear more pronounced at the lower end of the employment growth distribution according to the quantile regression estimates.

\section{[Table 4 here]}

The quantile regressions also reveal substantial heterogeneity in the relationship between ownership change and the changes in labour demand of SOEs, indicating that the OLS estimates may not be provide a full description of the employment effects of domestic and foreign privatisations. However, before interpreting the results we should note again that the simple DID estimates may be biased as they do, arguably not control properly for the selection effect in ownership change. In order to deal with this we therefore estimate the DID model on the matched sample, where the sample has been constructed using the propensity score matching technique as described in Section 3. The results of these estimations are reported in Table 5. 
Note, firstly, that the coefficients on the control variables are largely similar to the results in Table 4, suggesting robustness of the coefficients. The only difference with regard to the control concerns the debt variable, which is now only statistically significant in one specification (column 6). Turning to the ownership change variables, a number of results are worth noting.

For domestic privatisations we find a negative coefficient on the contemporaneous treatment dummy in the OLS regression. This suggests that privatised firms have lower employment growth than firms that remained SOEs. ${ }^{19}$ As the quantile estimation indicates, however, this only holds for firms below the median of the employment growth distribution. More specifically, the results suggest that the poorer the growth performance of the firm (i.e., the lower the quantile of the growth distribution), the more pronounced the negative effect. For firms in the $10^{\text {th }}$ percentile of the employment growth distribution, for example, growth is 27 percent lower in the privatisation year compared to non-treated firms. This difference is only 12.9 percent for firms in the $25^{\text {th }}$ percentile and 2.5 percent for the median firms. The slower growth post-acquisition appears to be transitory, however, as the coefficient on the post privatisation dummy is statistically insignificant in all cases.

By contrast, the results for foreign acquisitions appear to paint a slightly different picture of post-treatment labour demand effects. There is evidence of a small (3 percent) negative and statistically significant effect on employment growth compared to nontreated firms only for privatised firms at the median of the employment growth distribution As with domestic privatisations, this negative effect appears to wear off quickly, however, as the coefficient on the post-acquisition dummy is statistically insignificant in this case.

\footnotetext{
${ }^{19}$ It is worth pointing out that this does not imply that employment growth is negative for privatised firms, but only that growth is less relative to the base group of SOEs that remained state-owned.
} 
From the regressions for the $75^{\text {th }}$ and $90^{\text {th }}$ quantile we find different results on the impact of foreign acquisitions. More specifically, the results from these regressions show that during the after acquisition, newly foreign-owned firms exhibit faster employment growth than non-treated SOEs. These positive effects suggest an average differential in the growth rate, compared to non-treated firms, of 5.5 percent for firms in the $75^{\text {th }}$ quantile and 12.5 percent for firms in the $90^{\text {th }}$ quantile of the growth distribution, respectively. The coefficient turns statistically insignificant for firms at the bottom end of the quantiles.

\section{[Table 5 here]}

The differences in the coefficients obtained for the effect of domestic privatisation and foreign acquisitions for the different quantiles suggest that it seems prudent to analyse how sensitive the coefficients are to the choice of the respective quantile. To investigate this issue we estimated the regressions at each quantile between 0.10 and 0.90 and plotted the coefficients for the two variables in Figures 1 and 2. It is obvious that the coefficients for domestic privatisation do not seem to be overly sensitive to the choice of quantile, as they are generally increasing over the quantiles, as shown in Figure 1a (contemporaneous effect of privatisation), whilst Figure $1 \mathrm{~b}$ shows clearly that around the $90^{\text {th }}$ percentile there is a significant drop in the coefficient one year after the domestic privatisation event. There are some fluctuations also for the foreign acquisition variables but these do not appear to be so grave as to cause any major concerns for the estimation results.

[Figures 1 and 2 here]

\section{Conclusions}

Only very few studies have dealt with the issue of nationality of ownership in evaluating the results of privatisation. This paper investigates the employment effects of 
domestic privatisation or foreign acquisition of Chinese State Owned Enterprises (SOEs) within a simple labour demand framework. We use a combination of propensity score matching and difference-in-differences in order to identify the causal effect of these types of ownership change on employment growth. We furthermore allow for different effects of the "treatment" on firms at different quantiles of the employment growth distribution, using the quantile regression estimator in addition to standard OLS techniques.

Our results suggest that, controlling for output growth, there is some evidence that domestic privatisation leads to lower employment growth compared to firms that did not undergo an ownership change. This, perhaps, may be indicative of an almost instantaneous increase in efficiency of labour use following the ownership change, as, for a given level of output growth, growth in labour demand are less than it would have been had the firm not been privatised. By contrast, there is some evidence that foreign acquisitions show higher employment growth in the post acquisition period than nonacquired SOEs. This should not be taken as evidence that the newly foreign owned firms are less efficient. One possible alternative interpretation is that there is an increase in employment in an anticipation of increasing output, i.e., the firm is getting ready to prepare itself to grow in terms of output. In order to verify or dismiss this conjecture a detailed investigation of output and productivity growth patterns would be necessary. While this is beyond the scope of this paper it is high on our future research agenda.

Another possible explanation for these results could be given by the presence of specific agreements about the workforce levels between the foreign acquirers and the local government authority selling the SOEs. While there is no national law in China which constrains foreigners in this sense, we cannot observe the presence of idiosyncratic agreements or exceptions to the general rule made by local authorities. If such binding 
contracts were important, however, then this should manifest itself immediately, rather than in the long run after the privatisation.

Furthermore, our findings of zero or positive employment growth effects of foreign acquisitions may also be due to possible technology transfer accompanying the foreign investment (e.g., Girma et al., 2006). If the new technology also necessitates the use of more skilled labour due to the introduction of more sophisticated production methods, this could counteract the negative effect on labour demand for less skilled workers. The two opposing effects on employment obviously might drive the insignificance of those coefficients. However, in order to be able to come to firmer conclusions on this, further research is necessary to investigate labour demand for different types of workers over longer time horizons.

Finally, our results are in line with those in Frydman et al. (1999), who find that privatisation to foreign owners leads to significantly fewer layoffs as compared with state firms, and their result holds controlling for revenue and productivity growth. This evidence should dissipate some fears that privatisation to foreign owners might bring about larger unemployment effects given the assumption that private owners are more aggressive in restructuring the over-manned post-communist enterprises.

\section{References}

Allen, F. and D. Gale (1999). 'Corporate Governance and Competition', WP Wharton School, University of Pennsylvania.

Bai, C., D. D. Li and Y. Wang (1997). 'Enterprise Productivity and Efficiency. When Is Up Really Down?’, Journal of Comparative Economics, Vol. 24, pp. 265-280.

Bishop, M. R. and J. A. Kay (1989). 'Privatization in the United Kingdom: Lessons from Experience’, World Development, Vol. 17, pp. 643-657.

Blundell, R. and Costa Dias, M. (2000). 'Evaluation methods for non-experimental data', Fiscal Studies, Vol. 21, pp. 427-468. 
Boardman, A. F., C. Laurin and A. Vining (2002). 'Privatization in Canada: Operating, Financial and Stock Price Performance with International Comparisons', Canadian Journal of Administrative Sciences, Vol. 19(2), pp. 137-154.

Boubakri, N. and J.-C. Cosset (1998). 'The Financial and Operating Performance of Newly-Privatized Firms: Evidence from Developing Countries', Journal of Finance, Vol. 53, pp. 1081-1110.

Boycko, M., A. Shleifer, and R. W. Vishny (1994). 'Voucher Privatization', Journal of Financial Economics, Vol. 35, pp. 249-266.

Boyland, O. and G. Nicoletti (2000). 'Regulation, Market Structure and Performance in Telecommunications, OECD Economic Department WP 237, Paris.

Brada, J. C. (1996). 'Privatization Is Transition - Or Is It?', Journal of Economic Perspectives, Vol. 10, pp. 67-86.

Buchinski, M (1998). 'Recent advances in quantile regression models', Journal of Human Resources, Vol. 33, pp. 88-126.

Cao, Y. Y. Qian and B. R. Weingast (1999). 'From Federalism, Chinese Style to Privatization, Chinese Style', Economic Transition, Vol. 7(1), pp. 103-131.

Dehejia, R. and S. Wahba (2002). 'Propensity score matching methods for nonexperimental causal studies’, Review of Economics and Statistics, Vol. 84, pp. 151161.

Djankov, S. (1999). 'Ownership Structure and Enterprise Restructuring in Six Newly Independent States’, Comparative Economic Studies, Vol. 41(1), pp. 75-95.

D’Souza, J. and W. L. Megginson (1999). 'The Financial and Operating Performance of Newly Privatized Firms in the 1990s’, Journal of Finance, Vol. 54, pp. 1397-1438.

(2000). 'Sources of Performance Improvement in Privatized Firms. A Clinical Study of the Global Telecommunications Industry', WP University of Oklahoma.

Dyck, I. J. (1997). 'Privatization in Eastern Germany, Management Selection and Economic Transition', American Economic Review, Vol. 87, pp. 565-597.

Ehrlich, I., G. Gallais-Hamonno, Z. Liu, and R. Lutter (1994). 'Productivity Growth and Firm Ownership: An Empirical Investigation', Journal of Political Economy, Vol. 102, pp. 1006-1038.

Frydman, R., C. Gray, M. Hessel and A. Rapaczynski (1999). 'When Does Privatization Work? The Impact of Private Ownership on Corporate Performance in the Transition Economies', Quarterly Journal of Economics, Vol. 114(4), pp. 11531191.

Frydman, R., M. Hessel and A. Rapaczynski (2000). 'Why Ownership Matters. Entrepreneurship and the Restructuring of Enterprises in Central Europe', C. V. Starr Center for Allied Economics WP, New York University.

Galal, A., L. Jones, P. Tandon, and I. Vogelsang (1994). Welfare Consequences of Selling Public Enterprises, Oxford, Oxford University Press.

Geroski, P.A. (1995). 'What do we know about entry?', International Journal of Industrial Organization, 13, 421-440.

Girma, S. (2005). "Safeguarding Jobs? Acquisition FDI and Employment Dynamics in UK Manufacturing", Review of World Economics, Vol.141 (1), pp. 165-178 
Girma, S., Y. Gong and H. Görg (2006) "Can you teach old dragons new tricks? FDI and innovation activity in Chinese state-owned enterprises”, CEPR Discussion Paper 5838

Girma, S. and H. Görg (2004) "Blessing or Curse? Domestic plants' survival and employment prospects after foreign acquisitions”, Applied Economics Quarterly, Vol. 50, pp. 89-110

Groves, T., Y. Hong, J. McMillan and B. Naughton (1994). 'Autonomy and Incentives in Chinese State Enterprises’, Quarterly Journal of Economics, Vol. 109(1), pp. 183209.

(1995). 'China's Evolving Managerial Labor Market', Journal of Political Economy, Vol. 103, pp. 873-892.

Harper, J. T. (2002). 'The Performance of Privatized Firms in the Czech Republic', Journal of Banking and Finance, Vol. 26(4), pp. 621-649.

Koenker, R. and G. Bassett, (1978). 'Regression Quantiles', Econometrica, 46, 33-50

Kornai, J. (1988). 'Individual Freedom and Reform of the Socialist Economy', European Economic Review, Vol. 32, pp. 233-267.

— (1993). 'The Evolution of Financial Discipline under the Post-socialist System', Kyklos, Vol. 46(3), pp. 315-336.

La Porta, R. and F. López-de-Silanes (1999). 'Benefits of Privatization: Evidence from Mexico’, Quarterly Journal of Economics, Vol. 114(4), pp. 1193-1242.

Laffont, J.-J. and J. Tirole (1993). A Theory of Incentives in Procurement and Regulation, Cambridge, MA, MIT Press.

Lau, L. J., Y. Quian and G. Roland (2000). 'Reform without Losers. An Interpretation of China's Dual-Track Approach to Transition', Journal of Political Economy, Vol. 108, pp. 120-143.

Leuven, Edwin, and Barbara Sianesi (2003). 'PSMATCH2: Stata module to perform full Mahalanobis and propensity score matching, common support graphing, and covariate imbalance testing'. Available at http://ideas.repec.org/c/boc/bocode/ s432001.html.

Li, W. (1997). 'The Impact of Economic Reform on the Performance of Chinese State Enterprises, 1980-1989', Journal of Political Economy, Vol. 105, pp. 1080-1106.

Lin, C. (2000). 'Corporate Governance of State-Owned Enterprises in China', WP Asian Development Bank, Manila.

Lin, Justin.Y., Fang, Cai, Zhou, Li (1998).'Policy Burdens, and State-Owned Enterprise Reform', American Economic Review, Papers and Proceedings 88(2), 442-427.

Macquieira, C. and S. Zurita (1996). 'Privatizaciones en Chile, Eficiencia y Politicas Financieras, Estudios de Administracion, Vol. 3(2), pp. 1-36.

Megginson, W. L., R. Nash, and M. van Randenborgh (1994). 'The Financial and Operating Performance of Newly Privatized Firms: An International Empirical Analysis', Journal of Finance, Vol. 49, pp. 403-452.

Megginson, W. L. and J. M. Netter (2001). 'From State to Market: A Survey of Empirical Studies on Privatization’, Journal of Economic Literature, Vol. 39, pp. 321-389. 
Meyer, B. (1995). 'Natural and quasi-experiments in economics', Journal of Business and Economic Statistics, Vol. 13, pp. 151-162.

Mihályi, P. (2000). 'FDI Through Cross-Border M\&A: The Post-Communist Privatization Story Reconsidered', WP UNCTAD, New York.

Nellis, J. (1994). 'Is Privatization Necessary?', Viewpoint Note 17, Washington DC, World Bank.

Newbery, D. and M. Pollitt (1997). 'The Restructuring and Privatization of Britain's CEGB: Was It Worth It?’, Journal of Industrial Economics, Vol. 45, pp. 269-303.

Ramamurti, R. (1997). 'Testing the Limits of Privatization Argentine Railroads', World Development, Vol. 25, pp. 1973-1993.

Ros, A. J. (1999). 'Does Ownership or Competition Matter? The Effects of Telecommunications Reform on Network Expansion and Efficiency', Journal of Regional Economics, Vol. 15, pp. 65-92.

Rosenbaum, P. and Rubin, D. B (1983). 'The central role of the propensity score in observational studies for causal effects’, Biometrika, Vol. 70, pp.41-55.

Rosenbaum, P. and Rubin, D. B (1985). 'Constructing a Control Group Using a Multivariate Matched Sampling Method that Incorporates. the Propensity Score', The American Statistician, Vol. 39, pp. 33-38

Shirley, M. M. and L. C. Xu (1998). 'Information, Incentives, and Commitment: An Empirical Analysis of Contracts between Government and State Enterprises', Journal of Law and Economic Organization, Vol. 14(2), pp. 358-378.

Shleifer, A. (1998). 'State versus Private Ownership', Journal of Economic Perspectives, Vol. 12, pp. 133-150.

Smith, J. and Todd, P. (2005). “Rejoinder”, Journal of Econometrics, Vol. 125, pp. 365375.

Smith, S. C., B.-C. Cin, and M. Vodopivec (1997). 'Privatization Incidence, Ownership Forms, and Firm Performance: Evidence from Slovenia', Journal of Comparative Economics, Vol. 25, pp. 158-179.

Vickers, J. and G. Yarrow (1991). 'Economic Perspectives on Privatization', Journal of Economic Perspectives, Vol. 5, pp. 111-132.

Vining, A. R. and A. F. Boardman (1992). 'Ownership Versus Competition: Efficiency in Public Enterprise’, Public Choice, Vol. 73, pp. 205-239.

Wallsten, S. (2001). 'An Econometric Analysis of Telecommunications Competition, Privatization, and Regulation in Africa and Latina America', Journal of Industrial Economics, 49(1) pp. 1-19. 
Table 1

Frequency of domestic privatisation and foreign acquisitions

\begin{tabular}{|c|c|c|c|c|c|c|}
\hline & \multicolumn{3}{|c|}{ Whole sample } & \multicolumn{3}{c|}{ Matched sample } \\
\hline & Domestic & Foreign & Control & Domestic & Foreign & Control \\
\hline $\mathbf{2 0 0 0}$ & 15 & 15 & 16707 & & & \\
\hline $\mathbf{2 0 0 1}$ & 158 & 39 & 18461 & 128 & 33 & 153 \\
\hline $\mathbf{2 0 0 2}$ & 138 & 20 & 15313 & 94 & 15 & 105 \\
\hline $\mathbf{2 0 0 3}$ & 323 & 30 & 12206 & 305 & 30 & 316 \\
\hline Total & 707 & 104 & n/a & 527 & 78 & 574 \\
\hline
\end{tabular}

Table 2

Employment growth quantiles for matched sample

\begin{tabular}{|c|c|c|c|c|c|}
\hline & Control Group & Domestic & Privatised & Foreign & acquisition \\
\hline & & Before & after & before & after \\
\hline $\mathrm{q}=.1$ & -0.432 & -0.405 & -0.700 & -0.292 & -0.381 \\
\hline$q=.25$ & -0.137 & -0.112 & -0.246 & -0.092 & -0.133 \\
\hline$q=.50$ & -0.014 & 0.000 & -0.033 & 0.000 & 0.000 \\
\hline$q=.75$ & 0.000 & 0.014 & 0.027 & 0.081 & 0.078 \\
\hline $\mathrm{q}=.90$ & 0.122 & 0.204 & 0.247 & 0.346 & 0.245 \\
\hline mean & -0.090 & -0.033 & -0.125 & 0.015 & -0.032 \\
\hline Std.Dev. & 0.501 & 0.515 & 0.569 & 0.470 & 0.377 \\
\hline Observations & 1994 & 1064 & 848 & 140 & 151 \\
\hline
\end{tabular}

Table 3

Summary statistics

\begin{tabular}{|l|c|c|c|c|c|c|}
\hline & \multicolumn{2}{|c|}{$\begin{array}{c}\text { Full sample (unmatched } \\
\text { untreated) }\end{array}$} & \multicolumn{2}{c|}{ Matched untreated } & \multicolumn{2}{c|}{ Matched treated } \\
\hline Variables & Mean & Std.Dev & Mean & Std.Dev & Mean & Std.Dev \\
\hline Wage growth & 0.071 & 0.763 & 0.069 & 0.756 & 0.084 & 0.769 \\
\hline Output growth & -0.054 & 0.743 & -0.006 & 0.692 & 0.064 & 0.633 \\
\hline log debt & -0.647 & 0.763 & -0.609 & 0.684 & -0.656 & 0.701 \\
\hline log employment & 4.973 & 1.493 & 5.192 & 1.405 & 5.196 & 1.108 \\
\hline Intangible assets/total assets & 0.0182 & 0.069 & 0.02 & 0.076 & 0.029 & 0.083 \\
\hline $\begin{array}{l}\text { Labour productivity (log value } \\
\text { added per worker) }\end{array}$ & 2.622 & 1.390 & 3.398 & 1.296 & 3.497 & 1.151 \\
\hline
\end{tabular}


Table 4

OLS and Quantile regression estimates, full sample

\begin{tabular}{|c|c|c|c|c|c|c|}
\hline & & & & & & \\
\hline & OLS & $q=.1$ & $\mathrm{q}=.25$ & $q=.5$ & $q=.75$ & $\mathrm{q}=.9$ \\
\hline \multirow[t]{2}{*}{ Wage growth } & -0.369 & -0.327 & -0.250 & -0.124 & -0.107 & -0.219 \\
\hline & $(0.009) * * *$ & $(0.009)^{* * *}$ & $(0.002)^{* * *}$ & $(0.001)^{* * *}$ & $(0.001)^{* * *}$ & $(0.006) * * *$ \\
\hline \multirow[t]{2}{*}{ Output growth } & 0.148 & 0.178 & 0.119 & 0.052 & 0.038 & 0.076 \\
\hline & $(0.005)^{* * *}$ & $(0.008)^{* * *}$ & $(0.002)^{* * *}$ & $(0.001)^{* * *}$ & $(0.001)^{* * *}$ & $(0.005)^{* * *}$ \\
\hline \multirow[t]{2}{*}{ Age } & -0.030 & -0.018 & -0.018 & -0.014 & -0.022 & -0.065 \\
\hline & $(0.002)^{* * *}$ & $(0.005)^{* * *}$ & $(0.002)^{* * *}$ & $(0.001)^{* * *}$ & $(0.001)^{* * *}$ & $(0.004)^{* * *}$ \\
\hline \multirow[t]{2}{*}{ Debt } & -0.018 & -0.036 & -0.019 & -0.007 & -0.004 & -0.002 \\
\hline & $(0.002)^{* * *}$ & $(0.006)^{* * *}$ & $(0.002)^{* * *}$ & $(0.001)^{* * *}$ & $(0.001)^{* * *}$ & $(0.004)$ \\
\hline \multirow{2}{*}{$\begin{array}{l}\text { Domestic } \\
\text { privatisation } \\
\text { contemporaneous } \\
\end{array}$} & -0.053 & -0.164 & -0.098 & -0.014 & 0.001 & 0.016 \\
\hline & $(0.021)^{* *}$ & $(0.035)^{* * *}$ & $(0.014)^{* * *}$ & $(0.005)^{* * *}$ & $(0.005)$ & $(0.024)$ \\
\hline \multirow{2}{*}{$\begin{array}{l}\text { Domestic } \\
\text { privatisation post }\end{array}$} & 0.023 & 0.037 & 0.013 & 0.008 & 0.010 & 0.010 \\
\hline & $(0.010)^{* *}$ & $(0.022)^{*}$ & $(0.009)$ & $(0.003)^{* *}$ & $(0.003)^{* * *}$ & $(0.016)$ \\
\hline \multirow{2}{*}{$\begin{array}{l}\text { Foreign } \\
\text { acquisition } \\
\text { contemporaneous }\end{array}$} & 0.013 & 0.007 & -0.014 & -0.017 & 0.003 & -0.008 \\
\hline & $(0.038)$ & (0.089) & $(0.034)$ & $(0.013)$ & $(0.014)$ & $(0.062)$ \\
\hline \multirow{2}{*}{$\begin{array}{l}\text { Foreign } \\
\text { acquisition post }\end{array}$} & 0.079 & 0.160 & 0.040 & 0.018 & 0.048 & 0.019 \\
\hline & $(0.020) * * *$ & $(0.055)^{* * *}$ & $(0.021)^{*}$ & $(0.008)^{* *}$ & $(0.009)^{* * *}$ & $(0.039)$ \\
\hline \multirow[t]{2}{*}{ Constant } & 0.004 & -0.463 & -0.154 & 0.001 & 0.104 & 0.426 \\
\hline & $(0.011)$ & $(0.026)^{* * *}$ & $(0.010)^{* * *}$ & $(0.004)$ & $(0.004)^{* * *}$ & $(0.018)^{* * *}$ \\
\hline Observations & 59214 & 59214 & 59214 & 59214 & 59214 & 59214 \\
\hline R-squared & 0.31 & & & & & \\
\hline
\end{tabular}

\section{Notes:}

a. Robust standard errors in parentheses

b. significant at $10 \%$; ** significant at $5 \%$; *** significant at $1 \%$

c. all specifications include the full set of time, industry and regional dummies 
Table 5

OLS and Quantile regression estimates; based on sample of propensity score matched firms

\begin{tabular}{|c|c|c|c|c|c|c|}
\hline & $(1)$ & $(2)$ & (3) & (4) & (5) & (6) \\
\hline & OLS & $\mathrm{q}=.1$ & $q=.25$ & $q=.5$ & $q=.75$ & $\mathrm{q}=.9$ \\
\hline \multirow[t]{2}{*}{ Wage growth } & -0.298 & -0.236 & -0.163 & -0.087 & -0.097 & -0.183 \\
\hline & $(0.036) * * *$ & $(0.033) * * *$ & $(0.012)^{* * *}$ & $(0.003) * * *$ & $(0.004) * * *$ & $(0.016)^{* * *}$ \\
\hline \multirow[t]{2}{*}{ Output growth } & 0.144 & 0.144 & 0.107 & 0.056 & 0.055 & 0.094 \\
\hline & $(0.022)^{* * *}$ & $(0.038) * * *$ & $(0.014)^{* * *}$ & $(0.003)^{* * *}$ & $(0.004)^{* * *}$ & $(0.014)^{* * *}$ \\
\hline \multirow[t]{2}{*}{ Age } & -0.031 & -0.004 & -0.018 & -0.017 & -0.032 & -0.107 \\
\hline & $(0.009) * * *$ & $(0.021)$ & $(0.010)^{*}$ & $(0.003) * * *$ & $(0.003) * * *$ & $(0.010)^{* * *}$ \\
\hline \multirow[t]{2}{*}{ Debt } & -0.005 & 0.005 & 0.007 & 0.002 & -0.002 & -0.031 \\
\hline & $(0.011)$ & $(0.023)$ & $(0.011)$ & $(0.003)$ & $(0.004)$ & $(0.010)^{* * *}$ \\
\hline \multirow{2}{*}{$\begin{array}{l}\text { Domestic } \\
\text { privatisation } \\
\text { contemporaneous } \\
\end{array}$} & -0.080 & -0.270 & -0.129 & -0.025 & -0.010 & 0.034 \\
\hline & $(0.027)^{* * *}$ & $(0.046)^{* * *}$ & $(0.024)^{* * *}$ & $(0.006)^{* * *}$ & $(0.008)$ & $(0.022)$ \\
\hline \multirow{2}{*}{$\begin{array}{l}\text { Domestic } \\
\text { privatisation post }\end{array}$} & -0.031 & -0.064 & -0.043 & -0.006 & -0.001 & 0.012 \\
\hline & $(0.026)$ & $(0.057)$ & $(0.029)$ & $(0.008)$ & $(0.010)$ & $(0.028)$ \\
\hline \multirow{2}{*}{$\begin{array}{l}\text { Foreign acquisition } \\
\text { contemporaneous }\end{array}$} & -0.004 & -0.111 & -0.018 & -0.030 & -0.022 & 0.125 \\
\hline & $(0.050)$ & $(0.105)$ & $(0.053)$ & $(0.015)^{* *}$ & $(0.018)$ & $(0.047)^{* * *}$ \\
\hline \multirow{2}{*}{$\begin{array}{l}\text { Foreign acquisition } \\
\text { post }\end{array}$} & 0.080 & 0.073 & 0.033 & 0.022 & 0.055 & -0.022 \\
\hline & $(0.031)^{* * *}$ & $(0.101)$ & $(0.055)$ & $(0.015)$ & $(0.019) * * *$ & $(0.052)$ \\
\hline \multirow[t]{2}{*}{ Constant } & 0.086 & -0.273 & -0.105 & 0.026 & 0.146 & 0.485 \\
\hline & $(0.041)^{* *}$ & $(0.167)$ & $(0.094)$ & $(0.026)$ & $(0.030)^{* * *}$ & $(0.084)^{* * *}$ \\
\hline Observations & 4022 & 4022 & 4022 & 4022 & 4022 & 4022 \\
\hline R-squared & 0.23 & & & & & \\
\hline
\end{tabular}

Notes:

a. Robust standard errors in parentheses

b. significant at $10 \%$; ** significant at $5 \%$; *** significant at $1 \%$

All specifications include the full set of time, industry and regional dummies 
Figure 1: The effect of domestic privatisation on employment growth:

Point estimates and $95 \%$ confidence interval across all quantiles

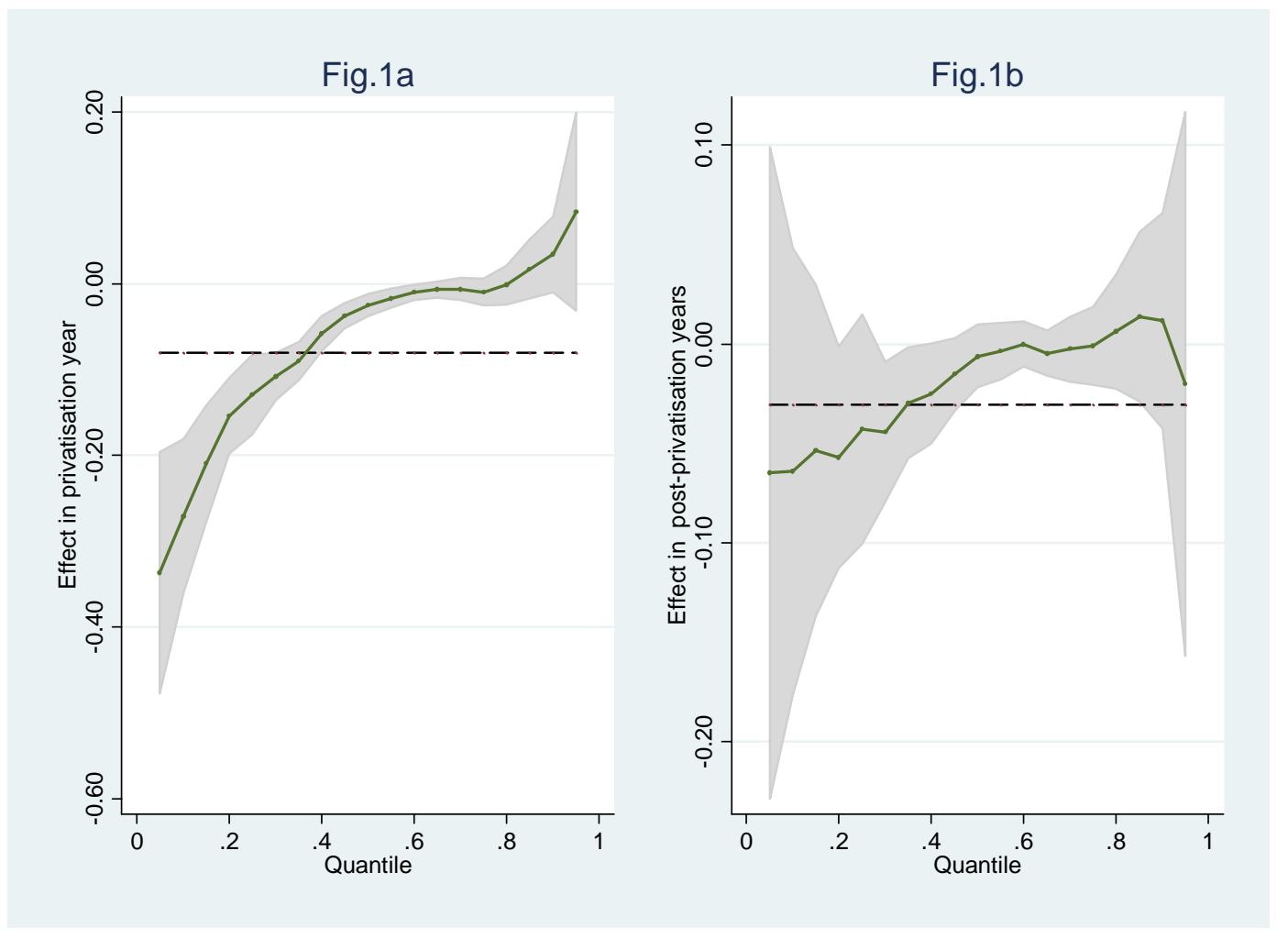

Figure 2: The effect of foreign acquisition on employment growth: Point estimates and $95 \%$ confidence interval across all quantiles
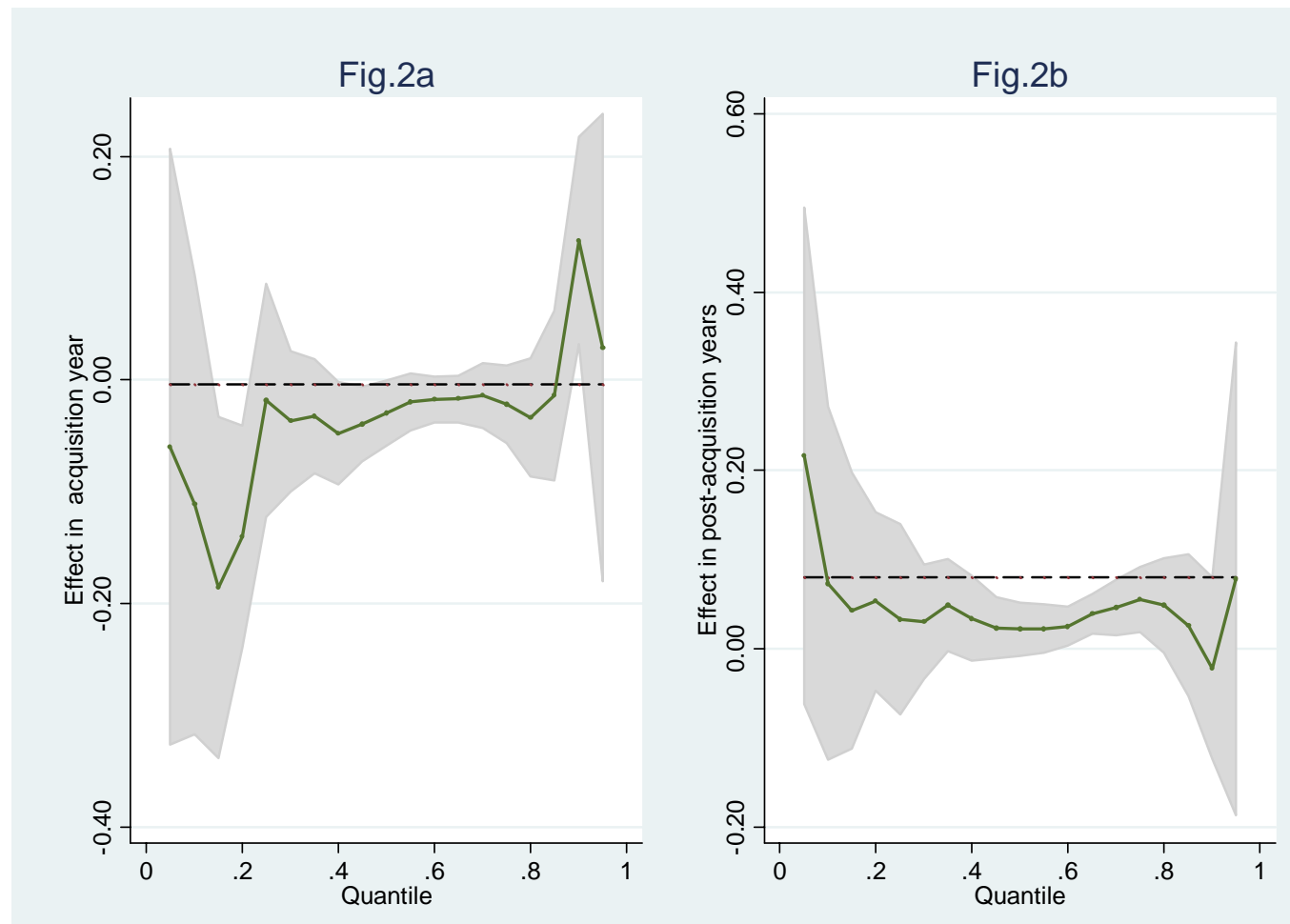


\section{Appendix: Results of balancing tests}

The first balancing test examines the standardised difference (or bias) for all variables in $\mathrm{X}$ (that is the vector of covariates used in the propensity score estimation) as described in Smith and Todd (2005). For example, the standardised bias for the employment level (size) variable is defined as the difference in means between the foreign acquired sample of firms (group $A$ ) and the appropriately matched comparison group of firms (group $C$ ) scaled by the average variances of the variable in groups A and C. Based on $N$ acquired firm this is given as

$$
\operatorname{SDIFF}(\text { size })=\frac{100 \frac{1}{N} \sum_{i \in A}\left[\text { size }_{i}-\sum_{j \in C} g\left(p_{i}, p_{j}\right) \operatorname{size}_{j}\right]}{\sqrt{\frac{\operatorname{Var}_{i \in A}(\operatorname{size})+\operatorname{Var}_{j \in C}(\text { size })}{2}}} .
$$

Note that the lower the standardised difference, the more balanced or similar the treatment and comparison groups will be in terms of the variable under consideration. Although there is no formal criterion as to how large a standardised bias should be for it to be considered serious, we follow Rosenbaum and Rubin (1985) and assume that a value of 20 is large. Furthermore, for each variable entering the propensity score model we perform a formal paired t-test between acquired and matched comparison to satisfy ourselves that no significant differences exist. The results of these two tests are reported in the tables below for the matching done for the years 2001, 2002 and 2003. 
Table A1: Balancing tests for matching for 2001

\begin{tabular}{|c|c|c|c|c|c|c|c|}
\hline \multirow[b]{2}{*}{ Variable } & \multirow[b]{2}{*}{ Sample } & \multicolumn{2}{|c|}{ Mean } & \multicolumn{2}{|c|}{ \%reduct } & \multicolumn{2}{|c|}{ t-test } \\
\hline & & Treated & Control & \%bias & |bias | & $\mathrm{t}$ & $p>|t|$ \\
\hline \multirow[t]{2}{*}{ L1_liquid } & Unmatched & -.5799 & -.61585 & 5.6 & & 0.64 & 0.519 \\
\hline & Matched & -.5799 & -.67496 & 14.8 & -164.4 & 1.31 & 0.190 \\
\hline \multirow[t]{2}{*}{ L1_intass } & Unmatched & .02947 & .01628 & 17.5 & & 2.63 & 0.009 \\
\hline & Matched & .02947 & .02826 & 1.6 & 90.8 & 0.12 & 0.903 \\
\hline \multirow[t]{2}{*}{ L1_Dlnemp } & Unmatched & -.05446 & -.05071 & -0.9 & & -0.09 & 0.927 \\
\hline & Matched & -.05446 & -.0148 & -9.8 & -957.2 & -0.70 & 0.483 \\
\hline \multirow[t]{2}{*}{ L1_Inemp } & Unmatched & 5.2928 & 5.1426 & 11.6 & & 1.29 & 0.199 \\
\hline & Matched & 5.2928 & 5.3004 & -0.6 & 94.9 & -0.05 & 0.960 \\
\hline \multirow[t]{2}{*}{ L1_Inprod } & Unmatched & 2.9894 & 2.5108 & 37.4 & & 4.50 & $\odot .000$ \\
\hline & Matched & 2.9894 & 3.0274 & -3.0 & 92.1 & -0.29 & 0.774 \\
\hline
\end{tabular}

Table A2: Balancing tests for matching for $\mathbf{2 0 0 2}$

\begin{tabular}{|c|c|c|c|c|c|c|c|}
\hline \multirow[b]{2}{*}{ Variable } & \multirow[b]{2}{*}{ Sample } & \multicolumn{2}{|c|}{ Mean } & \multicolumn{2}{|r|}{ \%reduct } & \multicolumn{2}{|c|}{$\mathrm{t}$-test } \\
\hline & & Treated & Control & \%bias & |bias | & $\mathrm{t}$ & $p>|t|$ \\
\hline \multirow[t]{2}{*}{ L1_liquid } & Unmatched & -.53703 & -.65479 & 16.1 & & 1.71 & 0.087 \\
\hline & Matched & -.53703 & -.57361 & 5.0 & 68.9 & 0.40 & 0.690 \\
\hline \multirow[t]{2}{*}{ L1_intass } & Unmatched & .02542 & .01913 & 9.6 & & 0.96 & 0.338 \\
\hline & Matched & .02542 & .03495 & -14.5 & -51.2 & -0.88 & $\odot .379$ \\
\hline \multirow[t]{2}{*}{ L1_Dlnemp } & Unmatched & -.07944 & -.12378 & 9.4 & & 0.87 & 0.387 \\
\hline & Matched & -.07944 & -.07012 & -2.0 & 79.0 & -0.17 & 0.864 \\
\hline \multirow[t]{2}{*}{ L1_Inemp } & Unmatched & 5.1482 & 5.0536 & 7.3 & & 0.68 & 0.493 \\
\hline & Matched & 5.1482 & 5.3528 & -15.8 & -116.4 & -1.18 & 0.238 \\
\hline \multirow[t]{2}{*}{ L1_Inprod } & Unmatched & 3.1974 & 2.6969 & 42.7 & & 4.20 & $\odot .0 \odot \odot$ \\
\hline & Matched & 3.1974 & 3.127 & 6.0 & 85.9 & 0.51 & 0.613 \\
\hline
\end{tabular}

Table A3: Balancing tests for matching for 2003

\begin{tabular}{|c|c|c|c|c|c|c|c|}
\hline \multirow[b]{2}{*}{ Variable } & \multirow[b]{2}{*}{ Sample } & \multicolumn{2}{|c|}{ Mean } & \multicolumn{2}{|c|}{ \%reduct } & \multicolumn{2}{|c|}{ t-test } \\
\hline & & Treated & Control & \%bias & |bias | & $\mathrm{t}$ & $p>|t|$ \\
\hline \multirow[t]{2}{*}{ L1_liquid } & Unmatched & -.6843 & -.66197 & -2.9 & & -0.53 & 0.594 \\
\hline & Matched & -.6843 & -.68178 & -0.3 & 88.7 & -0.04 & 0.968 \\
\hline \multirow[t]{2}{*}{ L1_intass } & Unmatched & .025 & 01967 & 7.2 & & 1.35 & 0.177 \\
\hline & Matched & .025 & .02628 & -1.7 & 76.0 & -0.22 & 0.824 \\
\hline \multirow[t]{2}{*}{ L1_Dlnemp } & Unmatched & -.03039 & -.06874 & 9.2 & & 1.62 & 0.105 \\
\hline & Matched & -.03039 & -.02225 & -2.0 & 78.8 & -0.28 & 0.780 \\
\hline \multirow[t]{2}{*}{ L1_Inemp } & Unmatched & 5.2273 & 5.091 & 10.9 & & 1.70 & $\odot .088$ \\
\hline & Matched & 5.2273 & 5.1832 & 3.5 & 67.6 & 0.43 & 0.667 \\
\hline \multirow[t]{2}{*}{ L1_Inprod } & Unmatched & 3.2066 & 2.846 & 29.6 & & 4.96 & 0.000 \\
\hline & Matched & 3.2066 & 3.2419 & -2.9 & 90.2 & -0.39 & 0.699 \\
\hline
\end{tabular}

